\title{
Design of new structure of multilevel inverter based on modified absolute sinusoidal PWM technique
}

\author{
Asef A. Saleh ${ }^{1}$, Rakan Khalil Antar ${ }^{2}$, Harith Al-Badrani ${ }^{3}$ \\ 1,2Technical Engineering College, Northern Technical University, Iraq \\ ${ }^{3}$ Department of Electronic Engineering, Ninevah University, Iraq
}

\begin{tabular}{|c|c|}
\hline Article Info & ABSTRACT \\
\hline Article history: & The advantage of multilevel inverters is to produce high output voltage \\
\hline Received Jun 17, 2021 & $\begin{array}{l}\text { values with distortion as minimum as possible. To reduce total harmonic } \\
\text { distortion (THD) and get an output voltage with different step levels using }\end{array}$ \\
\hline Revised Sep 11, 2021 & less power electronics switching devices, 15 -level inverter is designed in this \\
\hline Accepted Sep 18, 2021 & $\begin{array}{l}\text { paper. Single-phase } 11 \text {-switches with zero-level (ZL) and none-zero-level } \\
\text { (NZL) inverter based on modified absolute sinusoidal pulse width }\end{array}$ \\
\hline Keywords: & $\begin{array}{l}\text { modulation (MASPWM) technique is designed, modelled and built by } \\
\text { MATLAB/Simulink. Simulation results explained that, multilevel inverter }\end{array}$ \\
\hline Less power switches & with NZL gives distortion percent less than that with ZL voltage. The THD \\
\hline MASPWM & of the inverter output voltage and current of $\mathrm{ZL}$ are $4 \%$ and $1 \%$, while with \\
\hline Multilevel inverter & of the suggested power circuit and MASPWM controller to get the required \\
\hline Single phase & voltage with low THD. \\
\hline
\end{tabular}

Zero-level and none-zero-level inverter

This is an open access article under the CC BY-SA license.

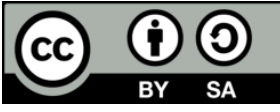

\section{Corresponding Author:}

Asef A. Saleh

Technical Engineering college/Mosul

Northern Technical University

Mosul, Iraq

Email: aasef.alhyali68@ntu.edu.iq

\section{INTRODUCTION}

The power inverters are designed to convert direct current (DC) voltages to alternating current (AC) voltages. The obtained AC voltages should have low distortion to keep the safety of the equipment. The highpower multilevel inverter circuits have more benefits than obtained from the conventional types. The generated different step levels of the output voltages for the intended multilevel inverters should be as sinewave as possible with lowest distortion (THD). Earlier, in symmetrical cascade inverter, each H-bridge cell in the multilevel cascaded H-bridge inverter has the same single DC input voltage with four power switching devices. To increase output levels in the AC voltages, DC inputs and switch devices should be increased. Therefore, the total cost of the system also will increase [1], [2]. The fast improvement of power electronics switches increases the required power converters with high performance and power quality applications [3]. Multilevel inverter can achieve the fundamental and high switching frequency based on PWM [4]. Increasing the multilevel inverter output voltage levels improve power quality of the output AC voltage and reduce THD [5], [6]. Different DC voltage values with lower power switch devices used past years to obtain high output voltage levels. Several control techniques presented to control the power electronics devices to get quality in the output waveform such as sinusoidal PWM, selective harmonics elimination PWM, space vector PWM, and multiple carrier SPWM [7]-[13].

In 2018, Geetha and Meenadevi [14], a new cascaded H-bridge multilevel inverter (MI) with less power switches were proposed. This MI uses 7 switches to provide 15-level output depending on SPWM to 
reduce the difficulty of switching. The THD of the output voltage was $12.77 \%$ for resistive load and $8.98 \%$ of RL load. In the same year [15], cascade H-Bridge 15-level inverter based on cascade cells connection with reduced number of switches is suggested. The MI is used to drive three phase induction motors for variable speed applications. The suggested method uses 10 switches to obtain 15-level output voltage. The THD obtained for the output voltage is 6.86\%. Also, in 2018 [16], three cells inverter with 12-swithes and three input DC sources of $(1,3,9) V d c$ was simulated by MATLAB to get 27-level output voltage made on a modified absolute sinusoidal PWM (MASPWM) strategy. The AC voltage and current distortion values of a three-phase circuit and resistor-inductor (RL) load were $0.67 \%$ and $0.0857 \%$, while with single-phase the THD values were $1.165 \%$ and $0.238 \%$, respectively. In the same year [17], single-phase 127-level inverter with 16-swithes was built. The THD of the output voltage was 0.96\%. In 2019 Ramachandran et al. [18], 15level inverter with less semiconductor switches were suggested to reduce cost and THD and increase the number of output levels. The number of switches that used to give a 15-level output voltage was 8-switches, while the output voltage distortion was $2.09 \%$ of RL load. In the same year [19], a 13-level inverter with less power electronic devices and dc voltage sources was designed. The output voltage THD with zero-level (ZL) and with none zero-level (NZL) inverter was $9.5 \%$ and $12.5 \%$, respectively. This topology has 12 switches and $4 \mathrm{dc}$ sources. While reference [20] used circuit with 10 switches and $3 \mathrm{dc}$ sources to a get 15-level inverter with three dc sources. The THD of the output voltage was $4.9 \%$ with resistive load. Additional in 2019 [21], Multi-carrier SPWM technique with 15-level inverter was simulated and compared with conventional types at $1 \mathrm{kHz}$ and $2 \mathrm{kHz}$ carrier frequency. The number of switches used in this technique is 28 . The lowest distortion value of the output waveform at $1 \mathrm{kHz}$ is $6.71 \%$, while with $2 \mathrm{kHz}$ is $6.59 \%$. In 2020 ANTAR et al. [22], the same power and control circuits suggested by [16] used for sensorless speed and torque control of an induction motor at different operating conditions. The system gave good response and quality. Also, in 2020 [23], 10 power switches with three DC sources were used to produce a 15-level output voltage at constant duty cycle and frequency. In 2021 Subki et al. [24], level shifted multicarrier PWM based on phase disposition and opposition disposition with alternate phase opposition disposition techniques was compared with the phase shifted PWM technique to produce 11-level output voltage.

As a continuation of the previous study to gain a full understanding of the MI with lower power electronics switching device and good power system quality, a new structure of single-phase 15-level inverter based on MASPWM technique is suggested and modeled as illustrated in Figure 1. This circuit is designed to give different levels of output voltage with THD as minimum as possible. The MASPWM algorithm is used to trig the MI's switches. Consequently, improving the power quality in the system and get required output voltage is very important. The novelty of the suggested system is to get different output voltage levels with less switching devices and minimum distortion. The contribution of the recommended study is to improve the power system quality that raises the electrical power efficiency.

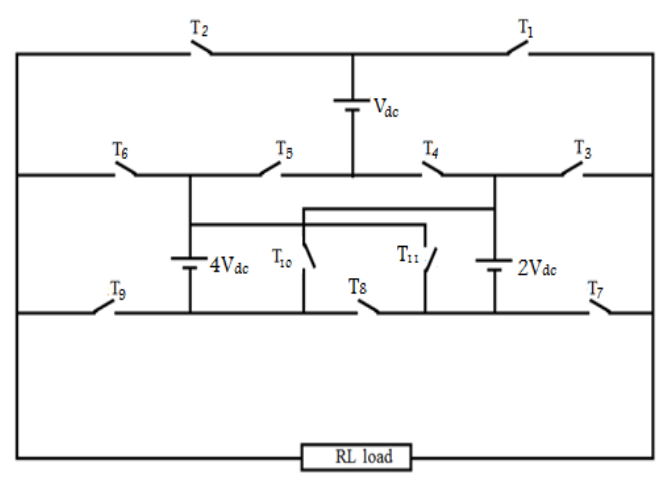

Figure 1. Proposed 15-level inverter topology

\section{PROPOSED 15-LEVEL INVERTER TOPOLOGY}

A new topology of MI has been designed to get 15-level output voltage as illustrated in Figure 2 (a). In the conventional MI circuit, a number of the main switches and dc sources to get any number of voltage levels are given by:

No. of switches $=2(\mathrm{~m}-1)$

No. of dc sources $=(m-1) / 2$ 
That means to get 15-level output voltage, the power circuit required 28-switches and 7-dc sources. The dc sources can be replaced by renewable energy sources to fulfill the requirements [25]. In the proposed circuit, a number of the main switches and dc sources are calculated as:

No. of switches $=(\mathrm{m}-4)$

No. of dc sources $=(m-3) / 4$

The suggested topology uses 11 -switches and 3-DC voltage sources $\left(\mathrm{V}_{\mathrm{dc}}, 2 \mathrm{~V}_{\mathrm{dc}}\right.$, and $\left.4 \mathrm{~V}_{\mathrm{dc}}\right)$ to get 15 level output voltage. Thus, the number of switches and dc sources is reduced by $61 \%$ and $57 \%$, respectively. All the 15-level cases of the proposed MI output voltages are explained in Table 1. Figure 2 (b)-(f) explains the connection diagram for the selected mode of operation according to switching states which is explained in Table 1.

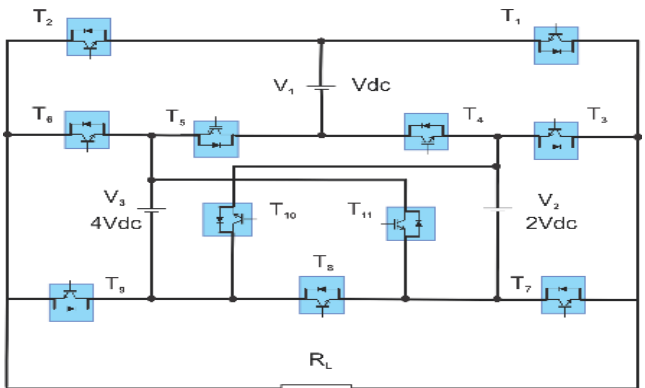

(a)

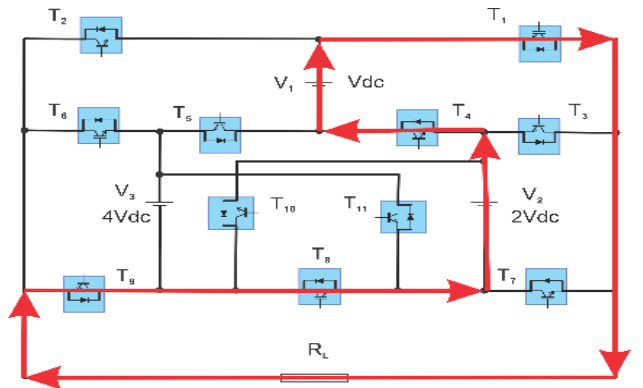

(c)

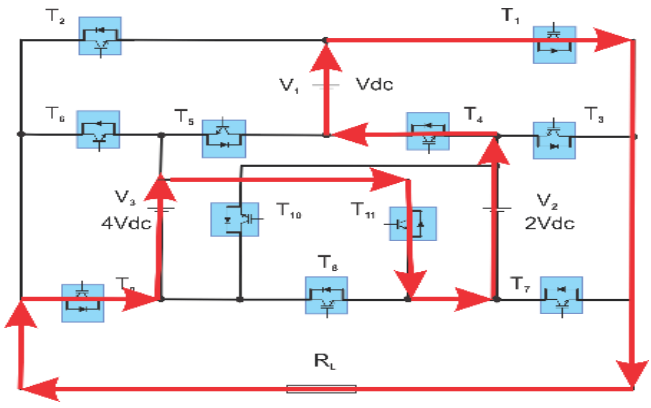

(e)

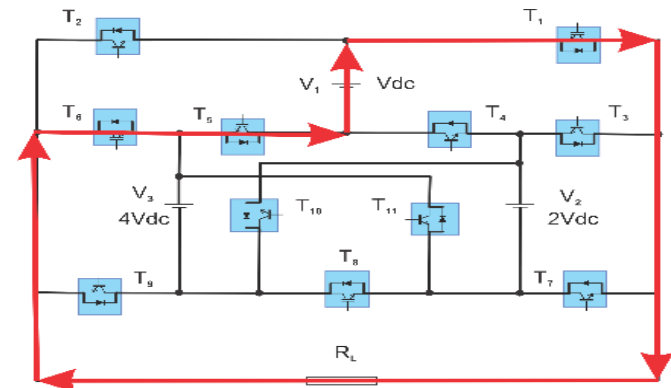

(b)

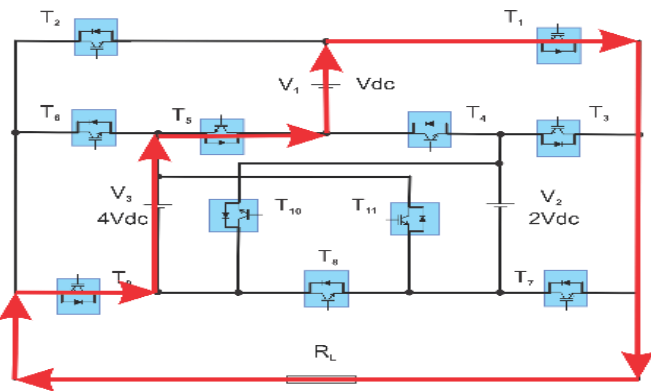

(d)

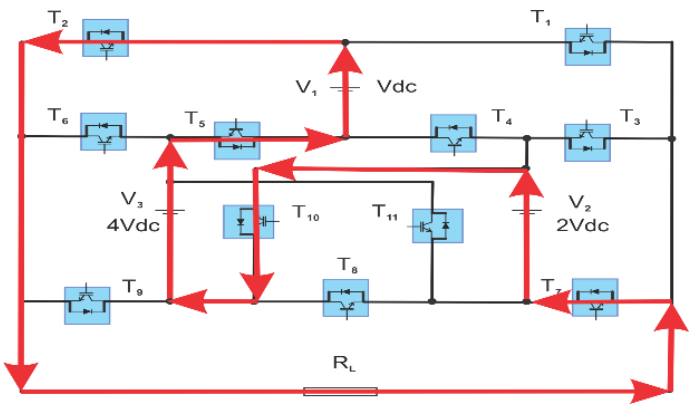

(f)

Figure 2. These figures are, (a) modeling of new proposed 15-level inverter topology, (b) selected path configuration with load voltage of Vdc, (c) $3 \mathrm{Vdc}$, (d) $5 \mathrm{Vdc}$, (e) $7 \mathrm{Vdc}$, (f) $-7 \mathrm{Vdc}$

Table 1. Switching table

\begin{tabular}{lccccccc}
\hline Output Voltage & $7 \mathrm{Vdc}$ & $6 \mathrm{Vdc}$ & $5 \mathrm{Vdc}$ & $4 \mathrm{Vdc}$ & $3 \mathrm{Vdc}$ & $2 \mathrm{Vdc}$ & $1 \mathrm{Vdc}$ \\
\hline ON switches & $1,4,9,11$ & $3,9,11$ & $1,5,9$ & $3,4,5,9$ & $1,4,8,9$ & $3,8,9$ & $1,5,6$ \\
Output Voltage & $-7 \mathrm{Vdc}$ & $-6 \mathrm{Vdc}$ & $-5 \mathrm{Vdc}$ & $-4 \mathrm{Vdc}$ & $-3 \mathrm{Vdc}$ & $-2 \mathrm{Vdc}$ & $-1 \mathrm{Vdc}$ \\
ON switches & $2,5,7,10$ & $6,7,10$ & $2,5,7,8$ & $6,7,8$ & $2,4,7$ & $4,5,6,7$ & $2,3,4$ \\
\hline
\end{tabular}




\section{MASPWM CONTROLLER}

A number of PWM techniques such as modulation frequency, harmonics mitigation, space vector, and carrier technique are used in multilevel power converter applications. In this study, a new control technique suggested by [16], MASPWM technique, is designed and used to build a novel control circuit to produce PWM pulses of a 15-level inverter with NZL and with ZL MI as explained in Figure 3. At the start of the MASPWM controller, reference signaling with range present the requested output level of the MI is made. The proposed control system explained in Figure 3 is utilized to sense the crossing points (+ve and ve) of the reference sinusoid signal and produce an absolute sine wave with magnitude depicted the needed level voltage. Then, the absolute sine wave is converted to discrete signal with size comply with the absolute sine signaling size at discrete times. The variation among the absolute sine and discrete signals gives the MASPWM signal as illustrated in Figure 3. This signal is compared with a triangle signal to produce the required PWM pulse. The next step of the MASPWM controller is programming s-function based on the switch states illustrated in Table 1 to reproduce pules of the switches of the MI. The suggested control system is built to generate the output voltage levels depending on the arrangement of DC sources.

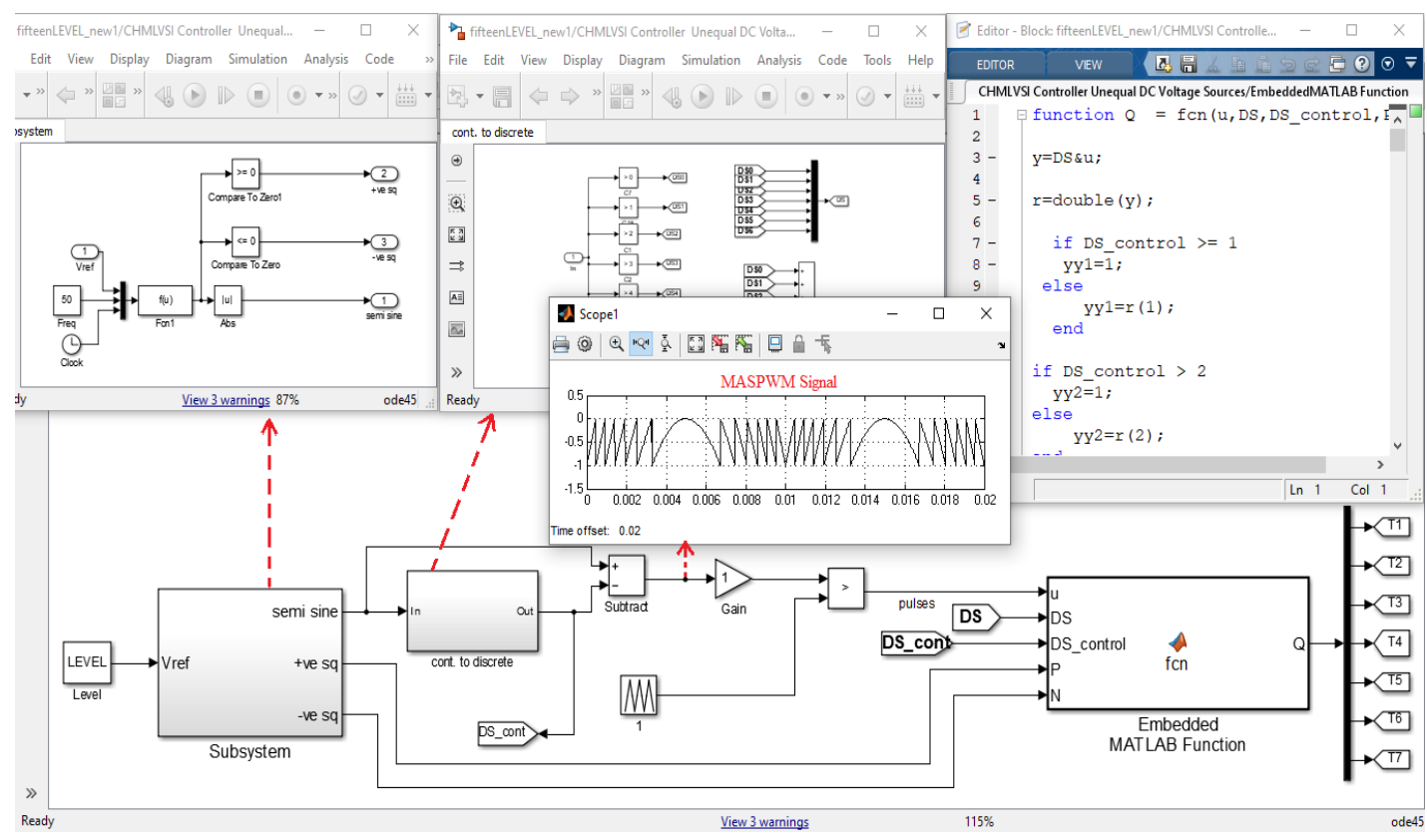

Figure 3. Control circuit of the proposed MI

\section{SIMULATION RESULTS}

The new topology of single-phase 15-level inverter with less power switching devices shown in Figure 2 (a) is designed and reformed to get levels higher than conventional type. To investigate the performance of the suggested power circuit, simulation by MATLAB/SIMULINK is carried out. The developed circuit consists of three DC voltage sources $\left(V_{d c}, 2 V_{d c}\right.$, and $\left.4 V_{d c}\right)$ and eleven main switches. The system is tested with NZL and ZL. The simulator results of the voltage $\left(\mathrm{V}_{\mathrm{S}}\right)$ and current $\left(\mathrm{I}_{\mathrm{S}}\right)$ with the spectrum analyser for 0.8-lag load are illustrated in Figure 4 and Figure 5 with NZL and with ZL. Figure 4 (a) and Figure 5 (a) illustrate the AC output voltage and current with NZL and ZL. Figure 4 (b) and Figure 5 (b) explain that the system with NZL gives THD better than with ZL, where the THD of $\left(\mathrm{V}_{\mathrm{S}}\right)$ and $\left(\mathrm{I}_{\mathrm{S}}\right)$ are $4.1 \%$ and $1 \%$ for ZL, and it is equal to $3.6 \%$ and $0.84 \%$ with NZL, respectively. The MASPWM technique can be programmed to get the voltage and current waveforms with NZL and with ZL. The THD results of $V_{S}$ and $\mathrm{I}_{\mathrm{S}}$ of MI with less power switches at various levels are shown in Figure 6 (a) and Figure 6 (b). It can be seen that THD results of NZL circuit is less than with ZL circuit. These results explain that MASPWM controller technique gives better quality results with NZL waveforms than with ZL. The THD value of the load voltage and current is reduced by $13.4 \%$ and $15.5 \%$ respectively at 15 -level state with NZL state. So, it is necessary to design MIs with NZL. The dynamic and steady-state waveform of the output voltage from 5level to 15-level with NZL are presented in Figure 7. 


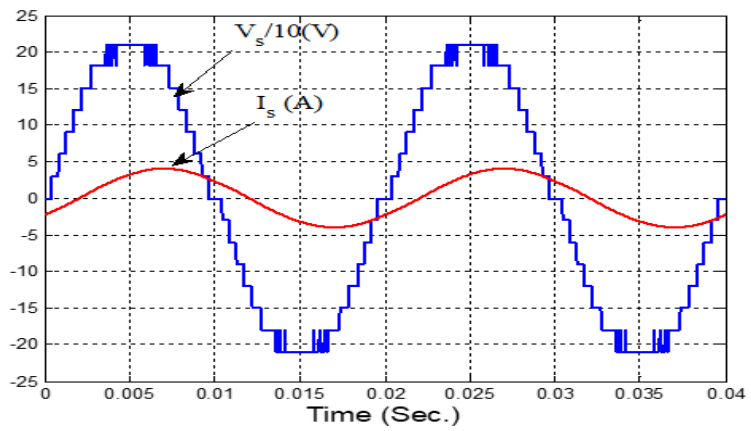

(a)

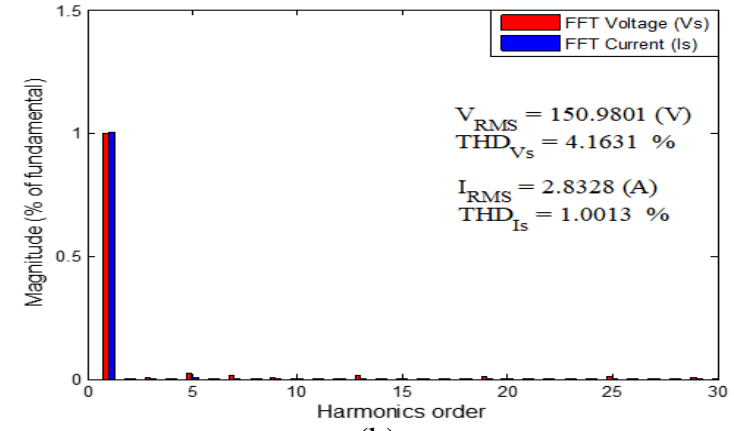

(b)

Figure 4. (a) Output MI voltage and current, and (b) spectrum analyzer of the 15-level inverter with ZL state

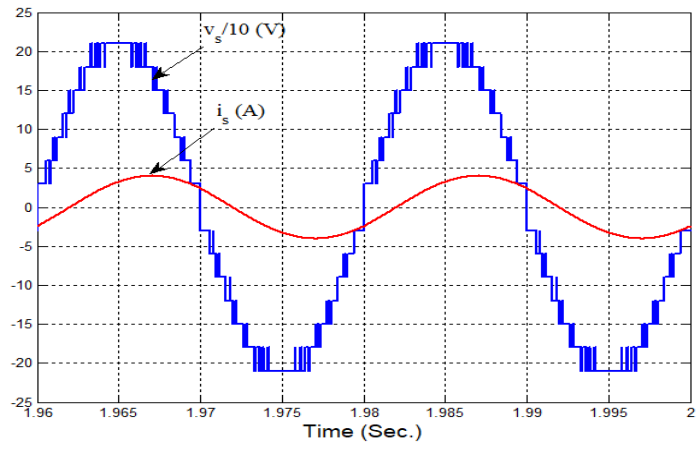

(a)

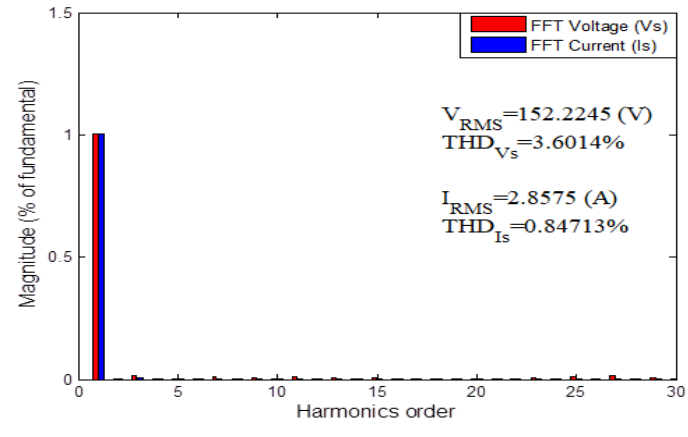

(b)

Figure 5. (a) Output MI voltage and current, and (b) spectrum analyzer of the 15-level inverter with NZL state

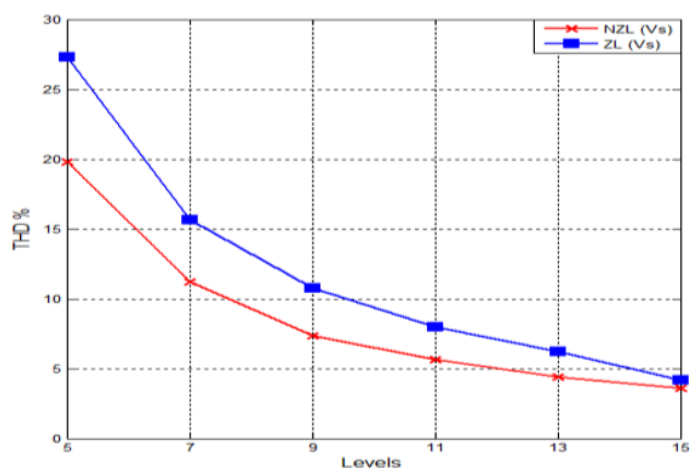

(a)

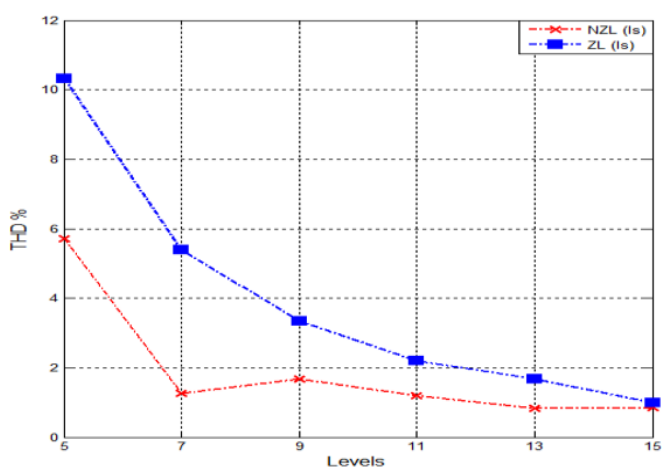

(b)

Figure 6. THD of the, (a) MI voltage, (b) current of the proposed MI with NZL and ZL states 

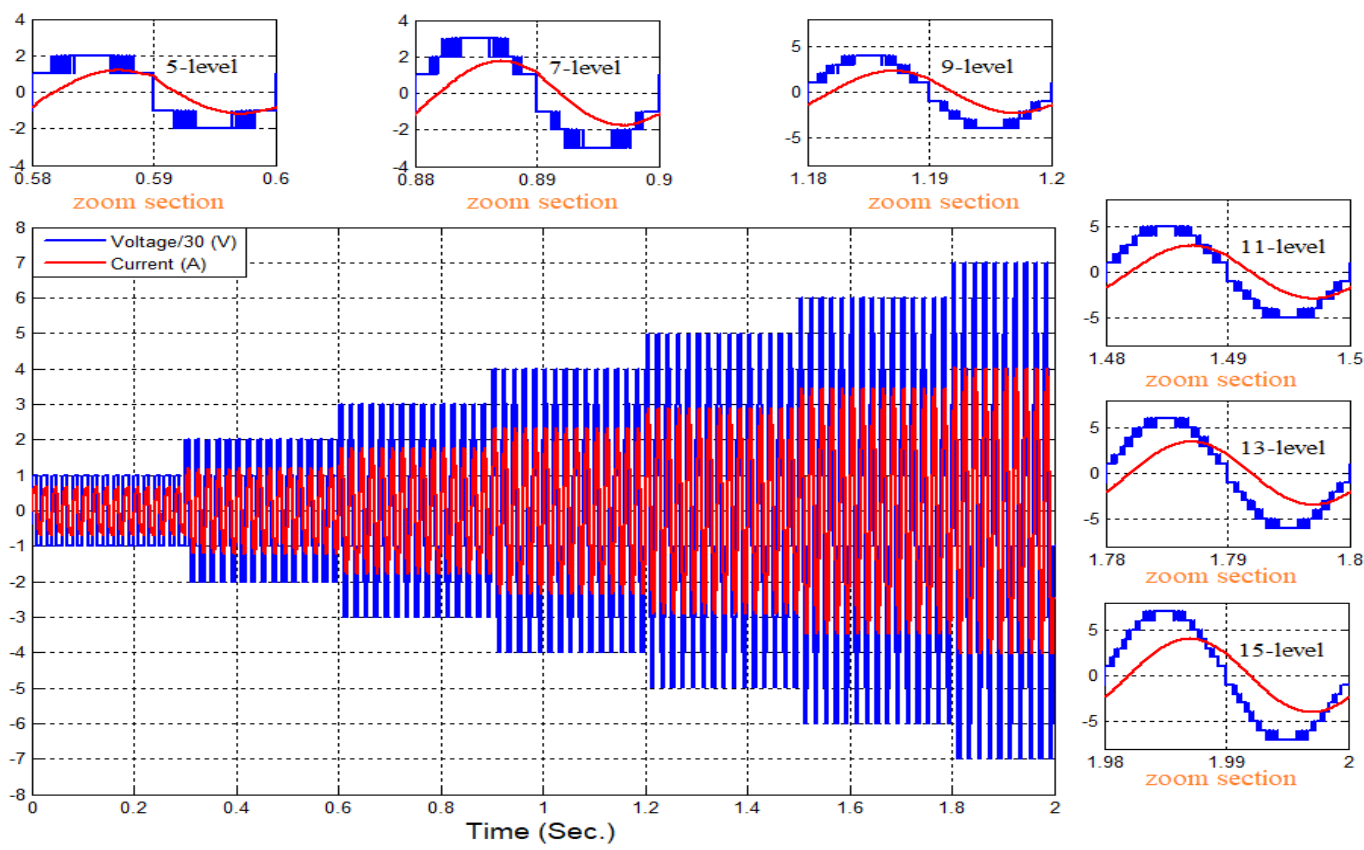

Figure 7. Different output voltage and current of the proposed MI with NZL

\section{CONCLUSION}

A MLI with 11 switches and three DC sources has been proposed in this paper. The key of the proposed multilevel inverter is to show that a multilevel inverter with less switching devices based on MASPWM control technique with NZL state gives THD results lower than with ZL state. The system is formed to give different voltage levels and minimum THD compared with conventional type. The system distortion for several levels and RL-load is existing. The system results explained the effectiveness of the proposed system with NZL and ZL states. The proposed MI with the MASPWM controller may well be used in industry-related use as low THD is required.

\section{REFERENCES}

[1] K. Dhineshkumar, C. Subramani, A. Geetha, C. Vimala, "Performance analysis of PV powered multilevel inverter", International Journal of Electrical and Computer Engineering (IJECE), vol. 9, no. 2, pp. 753-760, April 2019, doi: 10.11591/ijece.v9i2.pp753-760.

[2] H. S. Maaroof, H. Al-Badrani, and A. T. Younis, "Design and simulation of cascaded H-bridge 5-level inverter for grid connection system based on multi-carrier PWM technique," 1st International Ninevah Conference on Engineering and Technology, IOP Conf. Ser.: Mater. Sci. Eng., Iraq, vol. 1152, p. 0123034, April 2021.

[3] A. M. Al-Modaffer, A. Chlaihawi, and H. Wahhab, "Non-Isolated Multiple Input Multilevel Output DC-DC Converter for Hybrid Power System," Indonesian Journal of Electrical Engineering and Computer Science, vol. 19, no. 2, pp. 635-643, August 2020, doi: 10.11591/ijeecs.v19.i2.pp635-643.

[4] Y. Babkrani, A. Naddami, and M. Hilal, "A Smart Cascaded H-bridge Multilevel Inverter with an Optimized Modulation Techniques Increasing the Quality and Reducing Harmonics," International Journal of Power Electronics and Drive System (IJPEDS), vol. 10, no. 4, pp. 1852-1862, December 2019, doi: 10.11591/ijpeds.v10.i4.1852-1862.

[5] A. Seifi, M. Hosseinpour, A. Dejamkhooy, and F. Sedaghati, "Novel Reduced Switch-Count Structure for Symmetric/Asymmetric Cascaded Multilevel Inverter," Arabian Journal for Science and Engineering, vol. 45, pp. 6687-6700, 2020. doi:10.1007/s13369-020-04659-4.

[6] R. K. Antar, B. M. Saied, and R. A. Khalil, "Using seven-level cascade H-bridge inverter with HVDC system to improve power quality," 2012 First National Conference for Engineering Sciences, 2012, pp. 1-7, doi: 10.1109/NCES.2012.6740457.

[7] A. M. Amjad, Z. Salam, and A. M. A. Saif, "Application of differential evolution for cascaded multilevel VSI with harmonics elimination PWM switching," Electrical Power and Energy Systems, vol. 64, pp. 447-456, January 2015, doi: 10.1016/j.ijepes.2014.07.023.

[8] V. K. Gupta and R. Mahanty, "Optimized switching scheme of cascaded H-bridge multilevel inverter using PSO," Electrical Power and Energy Systems, vol. 64, pp. 699-707, January 2015, doi: 10.1016/j.ijepes.2014.07.072.

[9] V. Mahajan, P. Agarwal, and H. O. Gupta, "An artificial intelligence based controller for multilevel harmonic filter,” Electrical Power and Energy Systems, vol. 58, pp. 170-180, June 2014, doi: 10.1016/j.jiepes.2014.01.020. 
[10] I. H. Shanono, N. R. H. Abdullah, and A. Muhammad, "Five-Level Single Source Voltage Converter Controlled Using Selective Harmonic Elimination," Indonesian Journal of Electrical Engineering and Computer Science, vol. 12, no. 3, pp. 924-932, December 2018, doi: 10.11591/ijeecs.v12.i3.pp924-932.

[11] M. Khanfara, R. El Bachtiri, M. Boussetta, and K. El Hammoumi, "A Multicarrier PWM Technique for Five Level Inverter Connected to the Grid," International Journal of Power Electronics and Drive System (IJPEDS), vol. 9 , no. 4, pp. 1774-1783, December 2018, doi: 10.11591/ijpeds.v9.i4.pp1774-1783.

[12] S. K. Dash, B. Nayak, and J. B. Sahu, "Selective Harmonic Elimination of an Eleven Level Inverter Using Whale Optimization Technique," International Journal of Power Electronics and Drive System (IJPEDS), vol. 9, no. 4, pp. 1944-1951, December 2018, doi: 10.11591/ijpeds.v9.i4.pp1944-1951.

[13] O. Salama, A. Tabyaoui, and M. Benchagra, "Control Methods on Three-phase Power Converters in Photovoltaic Systems," International Journal of Power Electronics and Drive System (IJPEDS), vol. 9, no. 4, pp. 1851-1865, 2018 December, doi: 10.11591/ijpeds.v9.i4.pp1851-1865.

[14] V.Geetha and R. Meenadevi, "A 15 Level Multilevel Inverter with Reduced Number of Switches," International Journal of Pure and Applied Mathematics, vol. 119, no. 15, pp. 1745-1751, 2018.

[15] K. B. Bhaskar1, S. V. Devarajan, and R. Karthick, "Implementation of Improved Cascaded Multicell 15 Level Inverter for Induction Motor Using Level Shifting Multicarrier PWM," International Journal of Pure and Applied Mathematics, vol. 119, no. 16, pp. 1121-1138, 2018.

[16] R. K. Antar, "Multilevel inverter with unequal and selected DC voltage sources using modified absolute sinusoidal PWM technique," 2018 1st International Scientific Conference of Engineering Sciences-3rd Scientific Conference of Engineering Science (ISCES), 2018, pp. 62-67, doi: 10.1109/ISCES.2018.8340529.

[17] B. M. Reddy, Y. V. S. Reddy, and M. V. Kumar, "Modeling and Simulation of 127 Level Optimal Multilevel Inverter with Lower Number of Switches and Minimum THD", International Journal of Power Electronics and Drive System (IJPEDS), vol. 9, no. 4, pp. 1765-1773, December 2018, doi:10.11591/ijpeds.v9.i4.pp1765-1773.

[18] Ramachandran, T. Viswanathan, and S. Shanmugasundaram, "Design of 15-Level inverter topology with reduced number of semiconductor switches for Stand-Alone Power Systems (SAPS)," International Journal of Innovative Technology and Exploring Engineering, vol. 8, no. 2S2, December 2018.

[19] H. M. Bassi and Z. Salam, "A New Hybrid Multilevel Inverter Topology with Reduced Switch Count and dc Voltage Sources," Energies, vol. 12, no. 977, p. 977, March 2019, doi: 10.3390/en12060977.

[20] M. Rawa, et al., "Design and Implementation of a Hybrid Single T-Type Double H-Bridge Multilevel Inverter (STDH-MLI) Topology," Energies, vol. 12, no. 9, p. 1810, May 2019, doi: 10.3390/en12091810.

[21] B. Youssef, N. Ahmed, H. Sanaa, and H. Mohamed, "Selective-Harmonic Elimination with an Optimized Multicarrier Modulation Techniques for Cascaded H-Bridge Multilevel Inverter," Journal of Applied Mathematics and Computation (JAMC), vol. 3, no. 1, pp. 574-582, 2019, doi: 10.26855/jamc.2019.01.001.

[22] R. K. ANTAR, E. H. SADIQ, and A. A. SALEH, "Asymmetrical Multilevel Inverter with Modified Absolute Sinusoidal PWM Technique for Sensorless Control of Induction Motor," Proceedings of the 1st International Multi-Disciplinary Conference Theme: Sustainable Development and Smart Planning, IMDC-SDSP2020, Cyperspace, EAI, 2020, doi: 10.4108/eai.28-6-2020.2297934.

[23] A. Chlaihawi, A. Sabbar, and H. Jedi, "A high-performance multilevel inverter with reduced power electronic devices," International Journal of Power Electronics and Drive System (IJPEDS), vol. 11, no. 4, pp. 1883-1889, December 2020, doi: 10.11591/ijpeds.v11.i4.pp1883-1889.

[24] A. S. R. A. Subki, et al., "Analysis on three phase cascaded H-bridge multilevel inverter based on sinusoidal and third harmonic injected pulse width modulation via level shifted and phase shifted modulation technique," International Journal of Power Electronics and Drive System (IJPEDS), vol. 12, no. 1, pp. 160-169, March 2021, doi: 10.11591/ijpeds.v12.i1.pp160-169.

[25] R. K. Antar, N. S. Sultan and A. J. Ali, "Speed Control of Three-Phase Induction Motor Fed by Renewable Energy Source," 2019 2nd International Conference on Electrical, Communication, Computer, Power and Control Engineering (ICECCPCE), 2019, pp. 7-12, doi: 10.1109/ICECCPCE46549.2019.203739.

\section{BIOGRAPHIES OF AUTHORS}

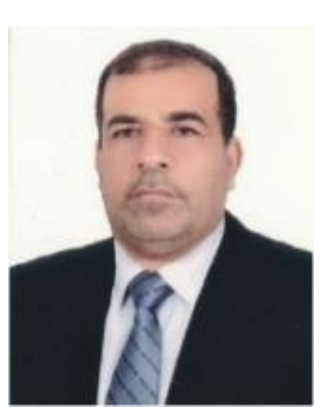

Asef Abdulelah Saleh received his BSc, M.Sc. and Ph. D. degrees from University of Mosul, Iraq in 1990, 2006, and 2018 respectively. Currently, he is a lecturer in Elect. Power Eng. dept. at Technical Engineering College, Northern Technical University. His research interests include power electronics, power quality, and power converters and drives. 


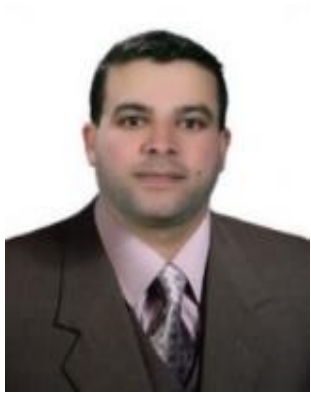

Rakan Khalil Antar got his B.Sc., M.Sc. and Ph. D. degrees from University of Mosul, Iraq in 2002, 2005 and 2013 respectively. Now, he is a lecturer at Technical Engineering College, Northern Technical University, Iraq. He is concerned in power electronics, power quality, power converters and drives, and renewable energies.

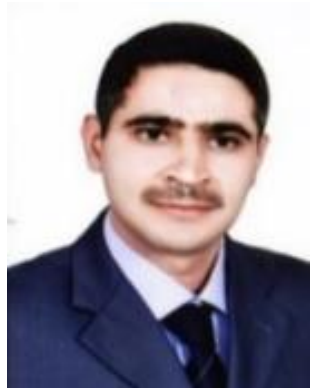

Harith Al-Badrani received the B.Sc and M.Sc. degrees in Electrical Engineering from Northern Technical University, Mosul, Iraq, in 2003 and 2006, respectively. Dr Al-Badrani got his Ph.D.-Ing. degree in Power Electronics and Electrical Drives at the Department of Electrical Engineering and Computer Science, University of Siegen, Germany in 2018. He worked as Scientific Researcher at University of Siegen from 2015 to 2018. Dr.-lng. AlBadrani currently working as a lecturer at College of Electronics Engineering, Ninevah University, Mosul, Iraq. His research interests focus on Power Electronics and Electrical Drives. 